\title{
Nutrients Turned into Toxins: Microbiota Modulation of Nutrient Properties in Chronic Kidney Disease
}

\author{
Raul Fernandez-Prado, Raquel Esteras, Maria Vanessa Perez-Gomez, Carolina Gracia-Iguacel, \\ Emilio Gonzalez-Parra, Ana B. Sanz, Alberto Ortiz and Maria Dolores Sanchez-Niño * \\ Raul Fernandez-Prado, IIS-Fundación Jiménez Díaz-Universidad Autónoma de Madrid, 28040 Madrid, Spain; \\ raul.fernandezp@quironsalud.es (R.F.-P.); raquel.esteras@quironsalud.es (R.E.); MVANESSA@fjd.es (M.V.P.-G.); \\ CGraciaI@quironsalud.es (C.G.-I.); egparra@quironsalud.es (E.G.-P.); asanz@fjd.es (A.B.S.); aortiz@fjd.es (A.O.) \\ * Correspondence: mdsanchez@fjd.es
}

Received: 14 March 2017; Accepted: 9 May 2017; Published: 12 May 2017

\begin{abstract}
In chronic kidney disease (CKD), accumulation of uremic toxins is associated with an increased risk of death. Some uremic toxins are ingested with the diet, such as phosphate and star fruit-derived caramboxin. Others result from nutrient processing by gut microbiota, yielding precursors of uremic toxins or uremic toxins themselves. These nutrients include L-carnitine, choline/phosphatidylcholine, tryptophan and tyrosine, which are also sold over-the-counter as nutritional supplements. Physicians and patients alike should be aware that, in CKD patients, the use of these supplements may lead to potentially toxic effects. Unfortunately, most patients with CKD are not aware of their condition. Some of the dietary components may modify the gut microbiota, increasing the number of bacteria that process them to yield uremic toxins, such as trimethylamine $\mathrm{N}$-Oxide (TMAO), p-cresyl sulfate, indoxyl sulfate and indole-3 acetic acid. Circulating levels of nutrient-derived uremic toxins are associated to increased risk of death and cardiovascular disease and there is evidence that this association may be causal. Future developments may include maneuvers to modify gut processing or absorption of these nutrients or derivatives to improve CKD patient outcomes.
\end{abstract}

Keywords: chronic kidney disease; caramboxin; microbiota; choline; carnitine; tryptophan; tyrosine; trimethylamine $\mathrm{N}$-Oxide (TMAO); p-cresyl sulfate; indoxyl sulfate; gut-kidney axis

\section{CKD and Uremic Toxins}

The prevalence of chronic kidney disease (CKD) hovers around $5-15 \%$ of the adult population and increases with age [1,2]. However, CKD frequently remains undiagnosed: it has been estimated that $9 \%$ of adults over the age of 80 years have been diagnosed with CKD, but around $60 \%$ have undiagnosed CKD [3]. For the past 20 years, CKD has been the second fastest growing cause of death worldwide, after HIV infection [4]. When the glomerular filtration rate (GFR) falls below $60 \mathrm{~mL} / \mathrm{min} / 1.73 \mathrm{~m}^{2}$, the risk of all-cause and cardiovascular death increases with decreasing GFR, peaking at 10- to 100-fold over the same-age general population in patients undergoing dialysis [5]. This is thought to result mainly from accumulation of uremic toxins [6]. For a solute to be considered a uremic toxin, it should meet two criteria, one related to the mechanism underlying accumulation in CKD and another related to the contribution to CKD manifestations. Thus, uremic toxins have been defined as solutes normally excreted by the kidneys that are retained in CKD and interact negatively with biologic functions $[7,8]$. The European Uremic Toxin (EUTOX) Working Group database presents encyclopedic data on 130 uremic toxins $[9,10]$. Interestingly, serum levels of some toxins are not well correlated with the levels of endogenous molecules excreted by glomerular filtration, such as creatinine. This may be explained by differences in the amount of ingested or generated toxins, on top of the generally shared reduction in clearance. In this regard, uremic retention solutes may represent 
molecules ingested with food, such as bisphenol A or caramboxin, may derive from nutrients, as discussed in this review, or from molecules generated during the normal functioning of the body, such as creatinine $[9,11,12]$. The current review focuses on uremic toxins that are primarily derived from ingested nutrients, either because the molecules are toxic in the biochemical form found in nutrients or because an intermediate metabolite is generated by the gut microbiota that is then processed to the uremic toxin. Thus, a lower ingestion of the nutrient precursors may favorably influence health in CKD patients. Since many CKD patients remain undiagnosed, a wider portion of the population and their doctors should be familiar with nutrients that may become toxins in the CKD context.

\section{The Microbiota}

The microbiome was originally defined as "the ecological community of commensal, symbiotic, and pathogenic microorganisms that literally share our body space" [13]. However, the term microbiota usually refers to the microorganisms, while microbiome is generally used to refer to their genes. The human body contains around 10 times more bacteria than individual human cells, mostly in the gastrointestinal tract [6]. Essentially, when humans feed themselves, they are also feeding their microbiota. The precise nutrients ingested will favor the growth of bacteria that feed on ingested nutrients, in detriment of bacteria that feed on nutrients that a person is not ingesting (Figure 1). Bacteria may even compete with the host for nutrients as discussed below for L-carnitine. There is a bidirectional interaction between the kidney and the gut microbiota (the gut-kidney axis): bacteria may generate potentially toxic metabolites while CKD may impact the composition of the microbiota and damage the intestinal epithelial barrier, facilitating translocation of endotoxins and live bacteria from gut lumen into the bloodstream [14]. Bacteria are also exposed to molecules released from gut cells. In this regard, genetic defects in the gut cell inflammasome (e.g., nlrp6 deficiency) alter the gut microbiota [15]. Conversely, bacteria release metabolites that may be absorbed and provide benefit (e.g., vitamin K) or harm (e.g., uremic toxin precursors). The influence of such bacterially secreted molecules is larger than previously suspected. Thus, higher plasma levels or uremic toxins of gut origin were associated with evidence of more severe systemic inflammation in CKD patients [16]. The gut microbiota impacts host metabolism and is thought to play a key role in obesity, insulin resistance and cancer, among others [17]. Microbiome-associated human conditions are being studied by the Integrative Human Microbiome Project [18,19]. Some general patterns of gut bacteria associated with disease are emerging. Thus, a decrease in Bacteroidetes species and an increase in Firmicutes species has been associated with the obese state, and an adverse metabolic profile [20].

The microbiota may be altered by many factors and, thus, may contribute more or less to the accumulation of uremic toxins. These factors include the genetic background of the host; the amount of dietary fiber, proteins and toxin precursors; medical conditions including CKD and certain therapies, especially antibiotics [21]. In this regard, in CKD patients, Brachybacterium, Catenibacterium, Enterobacteriaceae, Halomonadaceae, Moraxellaceae, Nesterenkonia, Polyangiaceae, Pseudomonadaceae, and Thiothrix families were markedly increased, while in CKD rats, Lactobacillaceae and Prevotellaceae families were decreased [22]. From a enzymatic point of view, ESRD patients exhibited significant expansion of bacterial families possessing urease, uricase, and indole and p-cresol forming enzymes, and contraction of families possessing enzymes converting dietary fiber to short-chain fatty acids such as butyrate [23]. 


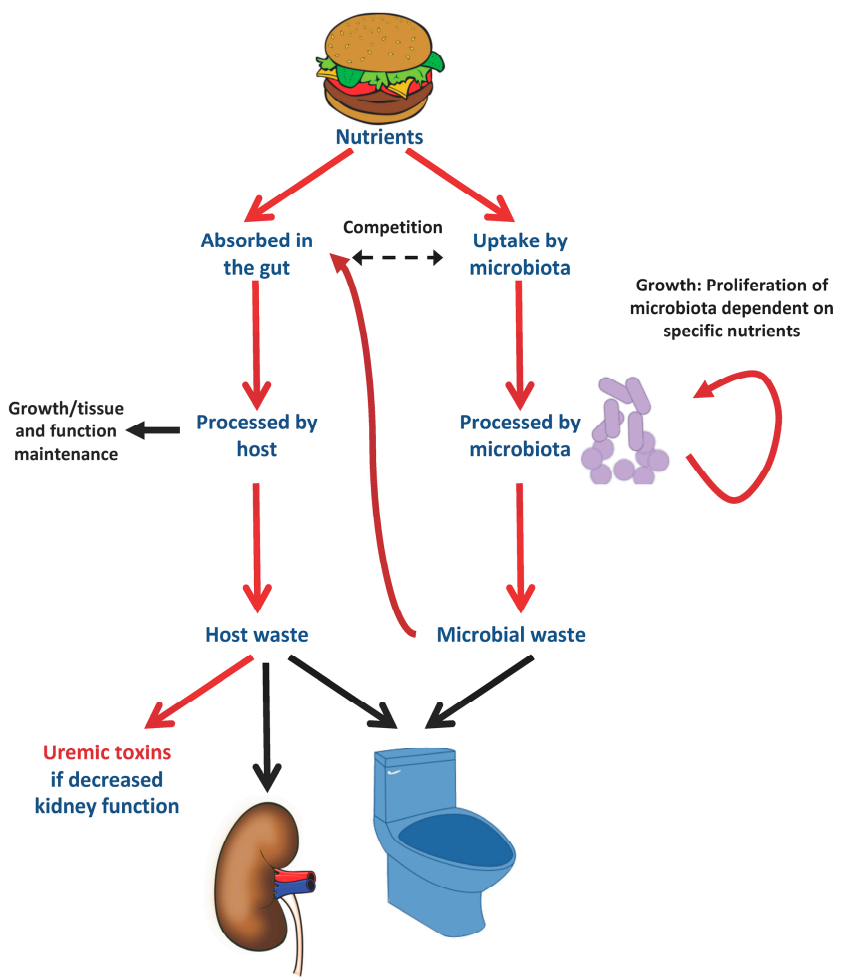

Figure 1. Microbiota-host interaction and modulation by dietary nutrients. When humans feed themselves, they are also feeding their microbiota. The precise nutrients ingested will favor the growth of bacteria that feed on ingested nutrients, in detriment of bacteria that feed on nutrients that a person is not ingesting. The microbiota competes with the host for certain nutrients, such L-carnitine. Thus, oral L-carnitine supplementation promotes the growth of L-carnitine metabolizing bacteria and may result in decreased L-carnitine absorption. Some waste molecules from bacterial feeding will be absorbed systemically and metabolized to uremic toxins that accumulate if not excreted in urine.

\section{Food-Derived Uremic Toxins}

Molecules found in food may be directly toxic. Some nutrients, such as phosphate or oxalate, may become toxic when accumulated in CKD. For other food components, such as caramboxin, there is no known nutritional benefit.

\subsection{Phosphate}

Around $1200 \mathrm{mg}$ phosphate are ingested daily with food, of which around $900 \mathrm{mg}$ are absorbed and must be excreted in urine [24]. Kidneys adjust serum phosphate levels and prevent phosphate accumulation. In CKD, phosphate accumulates and serum phosphate increases with decreasing GFR. Phosphate has been considered a uremic toxin associated with high cardiovascular risk in individuals with normal renal function and in CKD patients [24]. Serum phosphate in the high-normal range (normal range $2.5-4.5 \mathrm{mg} / \mathrm{dL}$ ) is associated to a higher risk of cardiovascular disease and mortality [25-29], as well as to faster CKD progression [30]. In observational studies, the use of phosphate binders was associated with lower mortality in patients on hemodialysis [31].

Dietary phosphate content used to be closely related to protein content and phosphate associated to animal proteins is better absorbed than phosphate from vegetable sources. However, in Western societies, inorganic phosphate from soda and food additives represents a rich source of very readily absorbed phosphate, not always associated to protein content, and not always well labeled in the processed food nutritional information.

The association between increased serum phosphate or phosphate overload and cardiovascular risk could result from direct promotion of cardiovascular injury, including vascular calcification $[32,33]$ 
or from adaptive mechanisms to excess phosphate. A positive phosphate balance activates the phosphatonins parathyroid hormone (PTH) and fibroblast growth factor-23 (FGF-23) that promote phosphaturia [34]. FGF-23 needs a cofactor, $\alpha$-Klotho, to activate the FGFR1 receptor [35]. In CKD, kidney inflammation downregulates Klotho, resulting in FGF-23 resistance and the need or even higher FGF-23 levels [36,37]. Lack of functional FGF-23 or Klotho is associated with premature aging, atherosclerosis and vascular calcification, which is prevented by a low phosphate diet [38]. In addition, FGF-23 downregulates calcitriol synthesis by inhibiting proximal tubular $1 \alpha$-hydroxylase [39] and increasing the 24-OH-hydroxylase activity that degrades calcitriol. Excess circulating FGF-23 and PTH, or reduced calcitriol levels, may also directly promote cardiovascular injury and interfere with antibacterial defenses [40-44].

\subsection{Caramboxin}

Caramboxin is a neurotoxin found in carambola (star fruit, Averrhoa carambola), a tropical fruit. Carambola has antioxidant properties and its use has been recommended to improve the lipid profile [45], depress pro-inflammation cytokines [46] and as a potential treatment for diabetes [47]. Carambola (Figure 2) may be found in supermarkets around the globe, but its toxicity in CKD patients remains poorly recognized by the general population and even less by those unaware of being CKD patients. The toxic effect of carambola was first reported in 1980 [48], but caramboxin was not described until 2013 [49]. Caramboxin is a nonpeptide amino acid, phenylalanine-like molecule that inhibits the GABAergic system through a glutamatergic ionotropic molecular action, having potent excitatory properties [49]. From 2000 to 2014 neurotoxicity related to carambola ingestion was reported in 110 patients, of whom 27 died [50]. The vast majority had CKD and developed neurotoxicity resulting from accumulation of caramboxin due to reduced renal excretion. However, the carambola fruit is also nephrotoxic and may cause both acute kidney injury (AKI) and neurotoxicity [51,52]. The amount of fruit consumed ranged from a glass of juice to 4 carambolas and symptoms started between $2 \mathrm{~h}$ and 2 days after ingestion. The initial presentations included uncontrollable hiccups (a typical manifestation found in over 90\% of patients), vomiting, mental confusion, seizures, coma and death [50]. Daily hemodialysis or continuous renal replacement methods is the therapy of choice for severe cases [53]. While oxalate nephropathy has been observed in renal biopsies from patients with carambola nephrotoxicity, the potential contribution of caramboxin to kidney injury has not been studied. In this regard, carambola juice is directly toxic for cultured tubular cells [54] and glutamatergic signaling was identified as a potential contributor to AKI by a systems biology, kidney tissue proteomics-based approach [55].
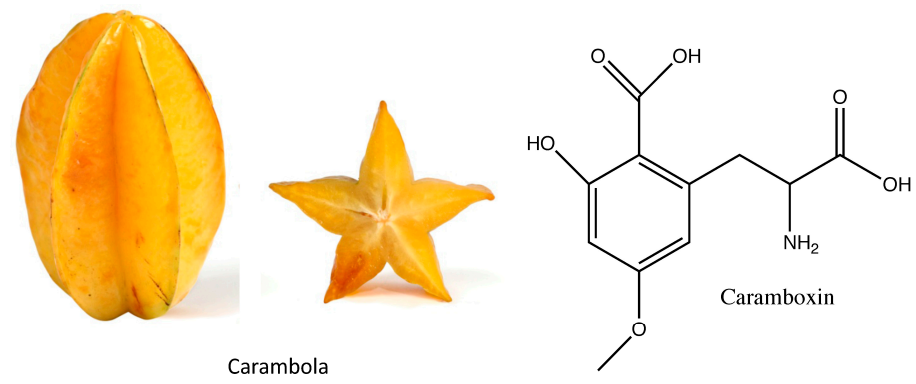

Figure 2. Carambola (star fruit) and caramboxin. CKD patients should be instructed to recognize and avoid carambola because of the risks it entails.

\subsection{Oxalate}

Plasma oxalate is increased in CKD patients and renal replacement therapy is not effective for permanently reducing oxalate levels [56]. As kidney function declines, the colon also gains importance in the homeostasis and disposal of oxalate. Oxalate colonic secretion may be increased by drugs 
increasing the expression of cAMP and by probiotics (e.g., Oxalobacter formigenes) [57]. Excess oxalate may become deposited and become nephrotoxic itself [58]. Indeed, as noted above, oxalate is thought to be the nephrotoxic component in carambola.

\section{Nutrients as Uremic Toxins Precursors via the Microbiota}

Some nutrients from food are processed by the gut microbiota to generate uremic toxins or precursors that are metabolized to toxins in the body. Trimethylamine N-Oxide (TMAO), p-cresyl-sulfate (pCS), indoxyl-sulfate (IS) and indole-3 acetic acid (IAA) are key uremic toxins originating from dietary nutrients (Figures 3 and 4).

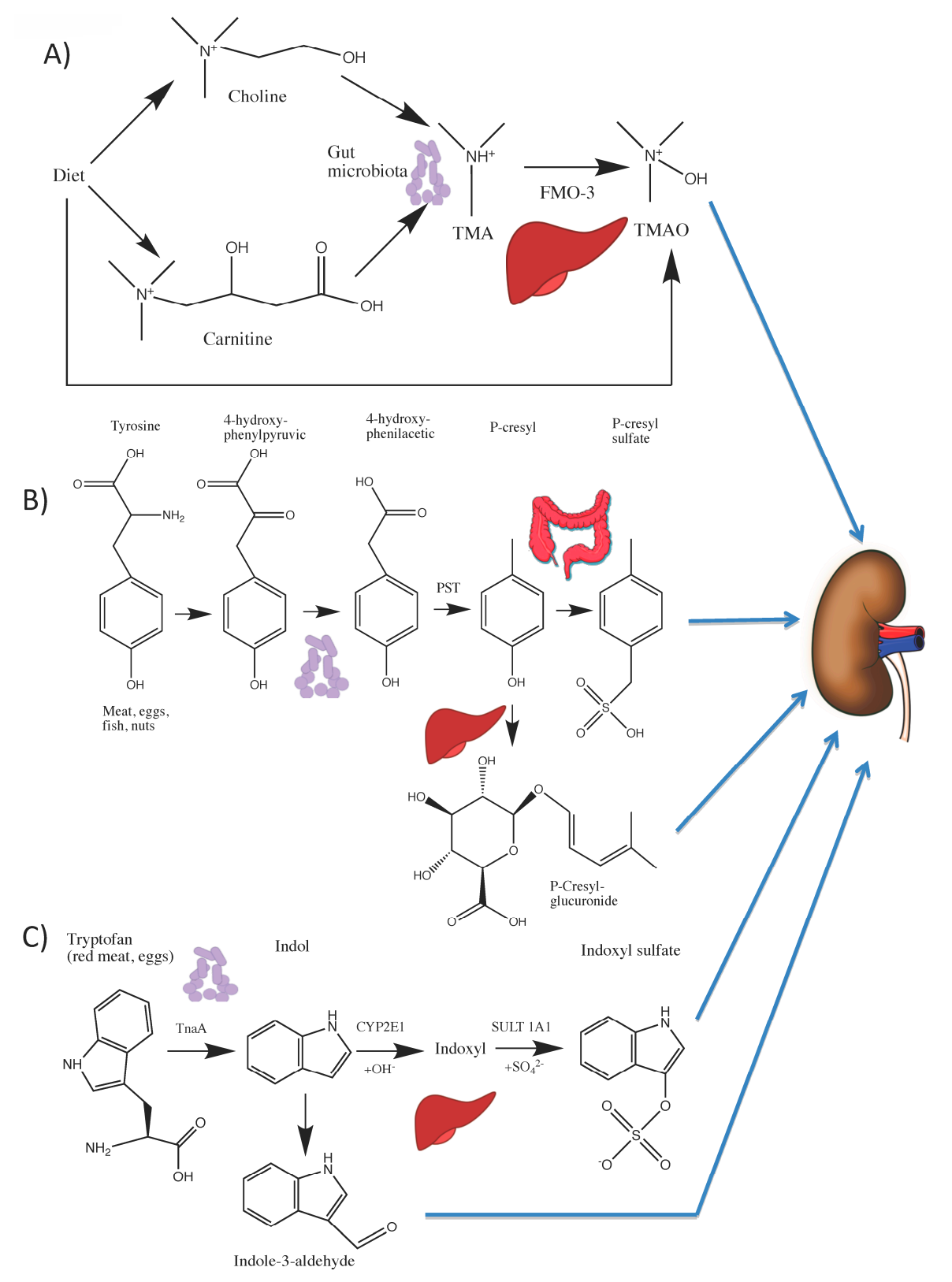

Figure 3. From nutrients to toxins: (A) Metabolic pathways for generation of the uremic toxin TMAO from dietary L-carnitine and choline; (B) metabolic pathways for generation of the uremic toxins p-cresyl-sulfate and p-cresyl-glucuronide from dietary tyrosine; and (C) metabolic pathways for generation of the uremic toxins indoxyl sulfate and indole-3-aldehyde from dietary tryptophan. The uremic toxins thus generated are excreted by the kidneys in healthy subjects but accumulate as uremic toxins in individuals with CKD. 


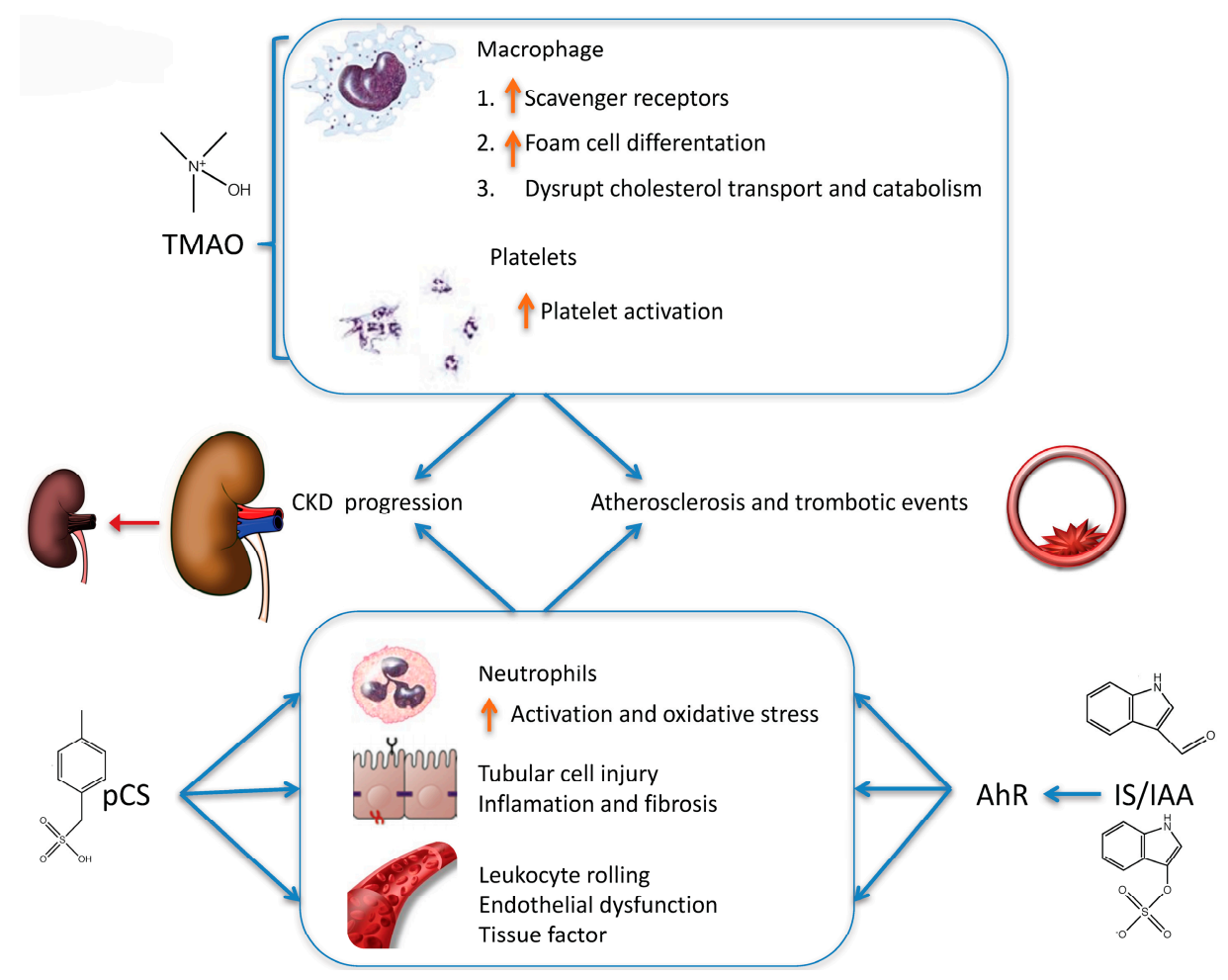

Figure 4. Mechanisms of toxicity for nutrient-derived uremic toxins. The molecular mechanisms of uremic toxin toxicity are starting to be elucidated. The figure represents some key recently described pathways by which they may contribute to the two key consequences of CKD: CKD progression and accelerated cardiovascular aging.

\subsection{Choline and L-carnitine Are Metabolized to TMAO}

Choline is an essential nutrient and quaternary ammonium salt containing the $\mathrm{N}, \mathrm{N}, \mathrm{N}$-trimethylethanolammonium cation. Choline is phosphorylated by choline kinase, generating phosphatidylcholine that incorporates into cell membranes. In the liver and kidney, choline is oxidized to betaine, which serves as a methyl donor. In neurons, choline acetyltransferase catalyzes its incorporation into the neurotransmitter acetylcholine [59]. There is an endogenous pathway for the de novo biosynthesis of choline via the sequential methylation of phosphatidylethanolamine using $S$-adenosylmethionine as the methyl donor. Thus, the demand for dietary choline is modified by metabolic methyl-exchange relationships between choline and three nutrients: methionine, folate, and vitamin B12 [60]. In this regard, choline is considered an essential nutrient by the Food and Nutrition Board of the Institute of Medicine, which recommends an adequate intake of $550 \mathrm{mg} /$ day for adult men and $425 \mathrm{mg} /$ day for adult women [61], although ingestion of around $1 \mathrm{~g} /$ day choline is common in healthy individuals. Lecithins added during food processing may increase the average daily intake of phosphatidylcholine [61]. Choline is widely distributed in foods, mostly as phosphatidylcholine in cell membranes and inadequate intake is unusual except in strict vegetarians who consume no milk or eggs. Foods especially rich in choline compounds include egg yolk (800 mg/100 g), kidney and liver (400 mg/100 g), chocolate- and protein-based beverages $(300 \mathrm{mg} / 100 \mathrm{~g})$, salmon and soy protein $(200 \mathrm{mg} / \mathrm{g})$, powdered milk $(170 \mathrm{mg} / 100 \mathrm{~g})$ and meat $(150 \mathrm{mg} / \mathrm{g})$ [62]. Choline is freely filtered at the glomerulus, but most $(97 \%)$ filtered choline is reabsorbed by proximal tubules, resulting in a renal clearance of around $2 \mathrm{~mL} / \mathrm{min}$. Higher choline levels are found in CKD patients, especially in dialysis patients [63]. Choline is cleared by dialysis and plasma free choline concentration falls during hemodialysis but returns to baseline levels $6 \mathrm{~h}$ later [63].

Choline is available as a dietary supplement as choline chloride or choline bitartrate and as lecithin, which usually contains approximately $25 \%$ phosphatidylcholine or $3-4 \%$ choline by weight. 
Choline supplements are marketed for liver health, memory and improved physical performance. In this regard, choline supplementation has been considered for a variety of conditions, including exercising, pregnancy and Alzheimer's disease [64,65]. Plasma choline concentration are reduced approximately $40 \%$ during marathon running [66]. However, preventing the decrease in plasma choline by short-term lecithin supplementation prior to a marathon failed to improve performance [67]. Furthermore, a recent systematic review concluded that evidence to confirm the suggested effects of choline on health in different stages of life is scarce [68]. Pharmacological doses of choline chloride ( $10 \mathrm{~g} /$ day) were associated to nausea, diarrhea, and a small fall in blood pressure in patients studied in the $70 \mathrm{~s}$ [69].

L-carnitine is an amino acid derivative that transports cytosolic long-chain fatty acids as acylcarnitines across the inner mitochondrial membrane for $\beta$-oxidation to generate ATP [70]. L-carnitine is obtained from dietary sources and from endogenous biosynthesis from lysine and methionine in kidneys and liver [71,72]. Meat has the highest contents of L-carnitine, including kangaroo meat $(637 \mathrm{mg} / 100 \mathrm{~g}$ of dry weight), horse meat $(423 \mathrm{mg} / 100 \mathrm{~g})$ and beef $(139 \mathrm{mg} / 100 \mathrm{~g})$. The amount of L-carnitine in milk products ranges from 1 to $43 \mathrm{mg} / 100 \mathrm{~g}$ of dry matter. Vegetables and fruits contain $<5 \mathrm{mg}$ L-carnitine $/ 100 \mathrm{~g}$ of dry matter. Mushrooms are richer in L-carnitine than plants. The amount of L-carnitine $(53 \mathrm{mg} / 100 \mathrm{~g}$ dry matter) in Pleureotus ostreatus equals approximately $100 \mathrm{~g}$ of minced pork [73]. Absorption of orally administered L-carnitine is very variable and ranges from $5 \%$ to $18 \%$ for pharmacological doses to up to $75 \%$ for dietary L-carnitine. The low bioavailability depends both on transport kinetics and on L-carnitine metabolism by intestinal bacteria as the number of L-carnitine processing bacteria increases when L-carnitine is abundant $[74,75]$. As it is the case for choline, the renal clearance of $\mathrm{L}$-carnitine $(1-3 \mathrm{~mL} / \mathrm{min})$ is low because of extensive tubular reabsorption. However, since there is a threshold concentration for tubular reabsorption, renal clearance is much higher following high dose intravenous L-carnitine [76].

Carnitine is an essential nutrient only in infants, according to the Food and Nutrition Board of the Institute of Medicine. L-Carnitine supplements are indicated to treat primary systemic carnitine deficiency, an ultrarare disease resulting from genetic defects in the high-affinity plasma membrane carnitine-carrier $r_{\text {in }}$ leading to renal carnitine wasting [77]. However, athletes may take L-carnitine supplements to boost performance and these supplements are marketed online to "burn fat".

More than $99 \%$ of the carnitine pool is located outside of plasma and, thus, plasma concentration is not a good marker of carnitine availability. During hemodialysis, large amounts of L-carnitine are lost in dialysate. Chronic hemodialysis may lead to progressive L-carnitine deficiency through a combination of loss of L-carnitine in dialysate and decreased L-carnitine synthesis by the injured kidney [78]. However, low renal clearance of short-chain acylcarnitines results in a high acylcarnitine:L-carnitine ratio in CKD patients. Intravenous and oral $\mathrm{L}$-carnitine for chronic renal failure anemia and intradialytic hypotension are licensed and reimbursed [79], although routine L-carnitine supplementation for hemodialysis patients is not recommended by clinical guidelines, based on lack of definitive evidence of benefit [80-84]. Despite this lack of endorsement of the practice, physicians may prescribe L-carnitine supplementation to hemodialysis patients given the potential benefit and perceived lack of adverse effects [85]. However, as discussed below, microbiota processing of oral L-carnitine in the gut may generate uremic toxins. In this regard, a meta-analysis suggested that oral L-carnitine increased serum cholesterol, but intravenous L-carnitine did not [86]. Different biological effects dependent on gut microbiota generation of toxins between oral and intravenous L-carnitine supplementation may have contributed to contradictory evidence [70].

TMAO is an amine oxide from dietary seafood. However, TMAO is mainly generated from dietary choline and D,L-carnitine. Choline and D,L-Carnitine are metabolized by gut microbiota to trimethylamine (TMA) [87], which is absorbed and oxidized by hepatic flavin monooxygenase-3 (FMO) to TMAO, which is eventually excreted, mainly in urine, but also in sweat and exhaled air (Figure 3A) [88-90]. Genetic deficiencies in FMO prevent conversion of maladorous TMA to odorless TMAO, resulting in trimethylaminuria or "fish odor syndrome" [91]. Plasma TMA, dimethylamine 
(DMA) and TMAO concentrations are elevated in uremia [92,93], because of decreased GFR with or without derangements in the gut microbiota [22]. Increased urinary TMAO levels in CKD patients may represent local renal TMAO synthesis or renal excretion of circulating TMAO [94], while hemodialysis efficiently removes TMAO from plasma [92].

Ingestion of precursors, genetic differences in the activity of enzymes involved in TMAO metabolism and the specific composition of the microbiota may account for large intra and interindividual differences in plasma TMAO levels among patients on dialysis $[88,91,95,96]$. Dose-dependent increases in circulating TMA and TMAO levels were observed in healthy volunteers following oral L-carnitine dosing [76]. In hemodialysis patients, oral L-carnitine did not change plasma TMA, but doubled plasma TMAO concentrations within two weeks [97]. By contrast, a report from Japan, a country where fish is an important dietary source of TMAO; observed an increase in circulating TMA levels but not of TMAO following oral L-carnitine [98]. Furthermore, predialysis TMAO levels in Japanese hemodialysis patients were in the range found in healthy volunteers. However, TMAO was increased in Australian patients on hemodialysis not supplemented with L-carnitine and in the absence of fish ingestion for $48 \mathrm{~h}[9,92]$. These differences are interesting given the long survival of Japanese dialysis patients and their low incidence of cardiovascular diseases [99]. Regarding potential ethnic differences, TMAO concentration did not differ between white and black hemodialysis patients. However, TMAO was associated with an increased risk of cardiac or all-cause death in whites, but not in blacks [100]. A phosphatidylcholine challenge (ingestion of two hard-boiled eggs) also increased plasma TMAO [101]. This response was suppressed by the administration of antibiotics to modify the microbiota and reappeared after withdrawal of antibiotics. In mice, antibiotics also prevented the increase in TMAO in response to oral L-carnitine and increased circulating L-carnitine levels following oral supplementation, presumably because of lower bacterial catabolism into TMA [88]. In mice, specific bacterial taxa in the gut were associated with higher TMAO levels and were altered in response to chronic dietary L-carnitine supplementation, resulting in markedly enhanced synthesis of TMA and TMAO. Thus, dietary L-carnitine itself induced the microbiota capacity to metabolize L-carnitine into TMA. TMAO itself favors the growth of anaerobic intestinal bacteria as Enterobacteriaceae and inhibits the growth of others as Staphylococcus aureus [90]. In this regard, omnivorous humans (eating red meat) produced more TMAO upon oral L-carnitine challenge than did vegans or vegetarians. However, an oral $250 \mathrm{mg}$ labeled L-carnitine challenge, had little impact on endogenous TMAO levels in subjects with normal renal function [88]. Given the large quantities of L-carnitine in red meats, L-carnitine and the microbiota may contribute to the causal link between high consumption of red meat and cardiovascular and renal risk [88]. Red meat intake, but not protein intake or protein from other sources, strongly associated with ESRD risk in a dose-dependent manner and substituting alternative sources of protein may reduce the incidence of ESRD [102].

Metabolomics identified plasma TMAO as a predictor of cardiovascular risk that was confirmed in an independent large clinical cohort [103]. High TMAO levels were associated with increased risk of mortality in CKD patients and with increased risk of renal disease progression in an animal model [93]. Higher TMAO levels are associated with a higher risk of major adverse cardiovascular events such as death, myocardial infarction or stroke [88,101,103-106], an advanced cardiometabolic risk profile [107], and higher incidence and poorer prognosis of heart failure [108,109]. Supplementation with L-carnitine or TMAO promoted atherosclerosis in mice [101]. The pro-atherogenic effect of TMAO may be related to upregulation of macrophage scavenger receptors involved in atherosclerosis, promoting foam cell differentiation [103] or to reduced reverse cholesterol transport and reduced expression of Cyp7a1, the rate limiting step in the catabolism of cholesterol [88]. TMAO also stabilizes the folded state of diverse proteins, functioning as a chemical chaperone [110] and enhances stimulus-dependent platelet activation from multiple agonists through increased $\mathrm{Ca}(2+)$ release from intracellular stores [111]. The contribution to any toxic effects of the chaperone function of TMAO is poorly characterized. TMAO stabilizes proteins through at least two mechanisms: (i) decreased hydrogen bonding ability of water and hence the stability of the unfolded state; and (ii) acting as 
a molecular crowder, that can increase the stability of the folded state via the excluded volume effect [110]. While initial studies focused on potential benefits derived from this chemical chaperone activity [112,113], more recent publications draw attention to a potential pathological impact in the absence of stressors, as potentiating the aggregation of amyloidogenic intrinsically disordered peptides, such as A $\beta 42$ [114]. By contrast, the potential pathological contribution of increased platelet aggregation is supported by epidemiological studies of an association between plasma TMAO and incident (three years) thrombosis (heart attack and stroke) risk and by animal studies employing dietary choline or TMAO, germ-free mice, and microbial transplantation that confirmed a role for gut microbiota and TMAO in modulating platelet hyperresponsiveness and thrombosis potential [111].

\subsection{Tryptophan Is Metabolized to Indoxyl Sulfate (IS) and Indole-3 Acetic Acid (IAA)}

Tryptophan (Trp, W) is an essential amino acid in humans, meaning that it cannot be synthesized and must be obtained from the diet. The FAO estimated the daily requirements in $3.5 \mathrm{mg} / \mathrm{kg} / \mathrm{day}$ in adults [115]. It is abundant in egg white $(1.4 \mathrm{~g} / 100 \mathrm{~g}$ of food), concentrated soy products and the cyanobacteria spirulina (Arthrospira platensis) $(0.93 \mathrm{~g} / 100 \mathrm{~g})$, milk and cheese $(0.5 \mathrm{~g} / 100 \mathrm{~g})$ and meat $(0.4 \mathrm{~g} / 100 \mathrm{~g})$. Tryptophan is a precursor for niacin and melatonin, thus taking part in the regulation of sleep disorders. Additionally, it is metabolized to 5-hydroxytryptophan which is subsequently converted into the neurotransmitter serotonin, a regulator of depression. Gut bacteria expressing tryptophanase metabolize tryptophan to indole and derivatives.

The kidneys excrete tryptophan derivatives and metabolize tryptophan via the kynurenine pathway. Higher levels of tryptophan in ESRD patients are associated with lower total cholesterol and systolic blood pressure [116]. In hemodialysis patients, tryptophan catabolites of the kynurenine pathway are increased perhaps due to an enhanced activity of tryptophan-degrading enzyme indoleamine 2,3-dioxygenase (IDO) inducible by pro-inflammatory stimuli [117,118]. Parkinson's disease, motor neuron disease and multiple sclerosis have been associated with the kynurenine pathway [119].

Tryptophan is sold over the counter as a dietary supplement for use as an antidepressant, anxiolytic and sleep aid. It has been proposed that consumption of tryptophan may improve depression, mood and anxiety disorders by increasing serotonin in the brain. However, this use of tryptophan is not supported by scientific evidence [120].

A variety of uremic toxins result from tryptophan metabolism, including indolic uremic toxins (IS, IAA, and indoxyl- $\beta$-D-glucuronide) and toxins from the kynurenine pathway (kynurenine, kynurenic acid, anthranilic acid, 3-hydroxykynurenine, 3-hydroxyanthranilic acid, and quinolinic acid) [121]. They are ligands of the transcription factor aryl hydrocarbon receptor (AhR), also known as the dioxin receptor. AhR activation is known to mediate cardiotoxicity, vascular inflammation, and a procoagulant and prooxidant phenotype of vascular cells [121].

Indoxyl Sulfate (IS) is an indole derivative that accumulates in uremia [122,123]. Bacterial tryptophanase (TnaA) from Citrobacter, Escherichia, and Proteus, among others, process tryptophan to indole [124]. Indole is absorbed and is oxidized in the liver to indoxyl by cytochrome p450-2E1 and then sulfated by sulfotransferase 1A1 to form IS [123] (Figure 3C). Lactobacillus species metabolize tryptophan into indole-3-aldehyde that can also be metabolized by the liver into IS [125,126].

The uremic toxicity of IS was recently reviewed and a role in vascular and renal disease progression was suggested [127]. In CKD patients, IS levels were inversely related with renal function and directly related to aortic calcification, and predicted all-cause and cardiovascular mortality [128], although not in all studies [129] and the association with CKD progression is weaker than for pCS [129]. IS may favor fibrosis and cellular senescence through activation of NADPH oxidase to generate reactive oxygen species (ROS), NFkB activation, Klotho downregulation, TGF- $\beta 1$ secretion, and inflammatory molecule (ICAM-1 and MCP-1) and senescence-related molecule (p21) expression [123,130]. IS may also be nephrotoxic, as it induced ER stress in tubular cells and inhibited cell proliferation [131]. In mice, IS suppressed endothelial progenitor cell-mediated neovascularization 
in ischemic limbs [132]. IS activates the aryl hydrocarbon receptor (AHR) that in turn interacts directly with and stabilizes functional tissue factor, preventing its ubiquitination and degradation and favoring thrombosis [133-135]. IS also enhanced platelet activities, including responses to collagen and thrombin, platelet-derived microparticles and platelet-monocyte aggregates, favoring thrombosis [136] and is a risk factor for dialysis graft thrombosis after endovascular interventions [137]. By contrast, AHR antagonists decreased tissue factor and were anti-thrombotic in uremia [133]. In the rat peritoneal vascular bed, IS disrupted the glycocalyx and induced strong leukocyte adhesion, enhanced extravasation, and interrupted blood flow [138]. IS also interferes with erythropoietin production, potentially favoring anemia in CKD patients [139], increases oxidative stress in osteoblasts, inducing PTH resistance and favoring adynamic bone disease [140] and promoted insulin resistance [141]. IS accumulated in muscles in murine CKD and caused mitochondrial dysfunction and decreased ATP availability in muscle cells. In CKD patients plasma IS inversely associated with and skeletal muscle mass [142].

Indole-3 Acetic Acid (IAA) predicted mortality and cardiovascular events in CKD patients. In cultured human endothelial cells, IAA activated an inflammatory AhR/p38MAPK/NF- $\mathrm{kB}$ pathway that induced the proinflammatory enzyme cyclooxygenase-2, and increased ROS production and tissue factor expression $[135,143]$.

\subsection{Tyrosine Is Metabolized to $p$-Cresyl Sulfate ( $p C S$ )}

L-tyrosine (para-tyrosine, Tyr, Y) or 4-hydroxyphenylalanine is considered a conditionally indispensable amino acid that can be synthesized from the essential amino acid L-phenylalanine in the liver. L-tyrosine is a precursor of several biologically active molecules, including catecholamine neurotransmitters, hormones, and melanin $[144,145]$. High amounts of tyrosine are found in egg white and dried soy products $(3 \mathrm{~g} / 100 \mathrm{~g})$, spirulina $(2.6 \mathrm{~g} / 100 \mathrm{~g})$, milk and cheese (1.5-2.5 g/100 g) and meat $(1.3 \mathrm{~g} / 100 \mathrm{~g})$ [62]. The FAO estimated the daily requirements of tyrosine and phenylalanine at $14 \mathrm{mg} / \mathrm{kg} /$ day in adults, around $1 \mathrm{~g} /$ day [115]. However, in the 1988-1994 NHANES III, the mean daily intake of tyrosine was $2.8 \mathrm{~g} /$ day. Young men had the highest intake at $6.4 \mathrm{~g} /$ day. This suggests that tyrosine supplementation is usually unnecessary. Indeed, tyrosine deficiency is rare. In hemodialysis patients, tyrosine levels were lower than in healthy controls and decreased with decreasing GFR [146,147].

A recent Cochrane Database review concluded that no recommendations can be made on tyrosine supplementation for routine clinical practice [148]. However, a number of studies have employed pharmacological doses of tyrosine, in the $150-500 \mathrm{mg} / \mathrm{kg} /$ day range [149]. In this regard, tyrosine is available as a dietary supplement. Reports on the effectiveness of tyrosine supplementation vary considerably, with some studies finding beneficial effects, whereas others do not. A recent review concluded that the potential of tyrosine supplementation for enhancing physical exercise capacity seems minimal. In contrast, tyrosine seemed to effectively enhance cognitive performance, particularly in short-term stressful and/or cognitively demanding situations, but only when neurotransmitter function is intact and dopamine and/or norepinephrine is temporarily depleted [149]. Studies investigating the role of tyrosine in cognitive function were performed in young adult populations and mostly under special conditions. Research in elderly populations is warranted [150]. Meta- and ortho-tyrosine are structural isomers of L-tyrosine (para-tyrosine) generated under conditions of oxidative stress and L-tyrosine supplementation has been suggested to potentially protect from oxidative stress-related diseases by competing with meta- and ortho-tyrosine [151].

Breakdown of tyrosine and phenylalanine by anaerobic intestinal bacteria, such as Bacteroides, Bifidobacterium, Lactobacillus, Enterobacter and Clostridium generate phenols as phenyl acetic acid and p-cresol [124]. p-cresol is absorbed in the gut and metabolized to pCS in enterocytes or to p-cresyl-glucuronide (pCG) in the liver [152,153] (Figure 3B). Although the older literature refers to increased p-cresol concentrations in CKD patients, this is an artifact generated by breakdown of pCS to $\mathrm{p}$-cresol during processing for the assay. In fact, free $\mathrm{p}$-cresol concentrations are undetectable or 
very low in plasma [152], while total serum pCS concentrations are four-fold higher than those of pCG [154]. While pCS is mostly protein-bound, only $8 \%$ of pCG is protein-bound, allowing a better clearance by dialysis. Moreover, pCG is less toxic than pCS on leucocytes and tubular cells [154,155]. In rat peritoneal vascular beds, pCS increased leukocyte rolling, while the combination of pCS and pCG impaired blood flow and vascular leakage but did not further enhance leukocyte rolling [156]. pCS has pro-apoptotic and pro-inflammatory effects on tubular cells [155]. Furthermore, in cultured tubular cells, pCS increased TGF- $\beta 1$ secretion and induced some features of EMT [130] and serum pCS levels were predictive of CKD progression and mortality $[129,157]$. The uremic toxicity of pCS was recently reviewed and a role in vascular and renal disease progression was suggested [127].

\section{Potential Therapeutic Implications}

The main message from this review is that physicians considering supplementing their patients with nutrients that may potentially yield uremic toxins should first assess the renal function of their patients. Additionally, physicians should also explore the dietary habits of their CKD patients, specifically asking about intake of nutritional supplements. On top of this, there is very active research on maneuvers to modify gut processing or absorption of these nutrients or derivatives to improve CKD patient outcome. AST-120 was approved for clinical use in Japanese CKD patients in 1991 to retard CKD progression. It adsorbs indole in the gut and lowers IS levels. However, it failed to prevent CKD progression in a large multinational trial $[158,159]$. In addition to the decrease in uremic toxins discussed above, depletion of the microbiota with broad-spectrum antibiotics decreased inflammation and attenuated renal damage caused by renal ischemia-reperfusion in mice while fecal transplants in antibiotic-treated mice abolished the protective effect of antibiotics [160]. However, antibiotics cannot be promoted to lower uremic toxin levels since the expected risks far exceed the foreseeable benefits.

Modulating the colon microbiota of CKD patients has been suggested as a means to regulate the synthesis of key uremic toxins. There are different ways to modulate the gut microbiota. A key one is a change in dietary habits, as suggested by L-carnitine and TMAO studies discussed above. The ClC-2 chloride channel activator lubiprostone, a therapy for constipation, favored the recovery of the levels of the Lactobacillaceae family and Prevotella genus, which were significantly reduced in renal failure mice, and decreased plasma IS, although it is unclear whether this was related to changes in the microbiota or to better preserved kidney function, as mice were protected from kidney injury [161]. Prebiotics, probiotics and synbiotics have been tested, aiming at improving the composition or activity of intestinal microbiota aimed at increasing saccharolytic bacteria and reducing proteolytic bacteria. However, there are no quality intervention studies demonstrating clinical benefit [6,162-164]. There are only small studies assessing the effect on uremic toxin levels. Prebiotics are non-digestible food ingredients that may change the composition or activity of intestinal microbiota. Oligofructose inulin reduced p-cresol in hemodialysis patients but it did not modify IS [165]. Probiotics are "live-microorganisms". Synbiotics are a combination of prebiotics and probiotics. In renal patients, synbiotics led to a reduction in pCS levels but not in IS levels and modified the stool microbiome, increasing bifidobacteria, in a proof-of-concept trial [166]. These results are consistent with another even smaller study in which a synbiotic combination of Lactobacillus casei, Bifidobacterium breve and galacto-oligosaccharide also decreased total p-cresol in hemodialysis patients [167]. An improved understanding of the gut microbial composition may allow the exploration of new potential treatment targets such as enzyme pathways [168].

Acknowledgments: Funds from FIS ISCIII FEDER (PI15/00298, PI16/02057, PI16/01900, ISCIII-RETIC REDinREN RD12/0021 RD16/0009), Funds from EUTOX, Funds from CYTED IBERERC. Programa Intensificación Actividad Investigadora (ISCIII) to AO. Miguel Servet CP14/00133 to MDSN.

Author Contributions: Raul Fernandez-Prado, Raquel Esteras, Maria Vanessa Perez-Gomez, Carolina Gracia-Iguacel, Emilio Gonzalez-Parra, Alberto Ortiz, and Maria Dolores Sanchez-Niño wrote the draft. Maria Dolores Sanchez-Niño designed the structure and integrated the different parts. RFP made Figures 3 and 4 . Alberto Ortiz made Figures 1 and 2 . All authors read and approved the final version. 
Conflicts of Interest: The authors declare no conflict of interest.

\section{References}

1. United States Renal Data System, 2014 Annual Data Report: Epidemiology of Kidney Disease in the United States. Available online: https://iths.pure.elsevier.com/en/publications/us-renal-data-system2014-annual-data-report-epidemiology-of-kidn (accessed on 20 April 2017).

2. Brück, K.; Stel, V.S.; Gambaro, G.; Hallan, S.; Völzke, H.; Ärnlöv, J.; Kastarinen, M.; Guessous, I.; Vinhas, J.; Stengel, B.; et al. CKD Prevalence Varies across the European General Population. J. Am. Soc. Nephrol. JASN 2016, 27, 2135-2147. [CrossRef] [PubMed]

3. Stevens, L.A.; Li, S.; Wang, C.; Huang, C.; Becker, B.N.; Bomback, A.S.; Brown, W.W.; Burrows, N.R.; Jurkovitz, C.T.; McFarlane, S.I.; et al. Prevalence of CKD and comorbid illness in elderly patients in the United States: Results from the Kidney Early Evaluation Program (KEEP). Am. J. Kidney Dis. 2010, 55, S23-S33. [CrossRef] [PubMed]

4. GBD 2015 Mortality and Causes of Death Collaborators. Global, regional, and national life expectancy, all-cause mortality, and cause-specific mortality for 249 causes of death, 1980-2015: A systematic analysis for the Global Burden of Disease Study 2015. Lancet 2016, 388, 1459-1544.

5. Ortiz, A.; Covic, A.; Fliser, D.; Fouque, D.; Goldsmith, D.; Kanbay, M.; Mallamaci, F.; Massy, Z.A.; Rossignol, P.; Vanholder, R.; et al. Epidemiology, contributors to, and clinical trials of mortality risk in chronic kidney failure. Lancet 2014, 383, 1831-1843. [CrossRef]

6. Vanholder, R.; Glorieux, G. The intestine and the kidneys: A bad marriage can be hazardous. Clin. Kidney J. 2015, 8, 168-179. [CrossRef] [PubMed]

7. Vanholder, R.; Fouque, D.; Glorieux, G.; Heine, G.H.; Kanbay, M.; Mallamaci, F.; Massy, Z.A.; Ortiz, A.; Rossignol, P.; Wiecek, A.; et al. Clinical management of the uraemic syndrome in chronic kidney disease. Lancet. Diabetes Endocrinol. 2016, 4, 360-373. [CrossRef]

8. Vanholder, R.; De Smet, R.; Glorieux, G.; Argilés, A.; Baurmeister, U.; Brunet, P.; Clark, W.; Cohen, G.; De Deyn, P.P.; Deppisch, R.; et al. Review on uremic toxins: Classification, concentration, and interindividual variability. Kidney Int. 2003, 63, 1934-1943. [CrossRef] [PubMed]

9. Duranton, F.; Cohen, G.; De Smet, R.; Rodriguez, M.; Jankowski, J.; Vanholder, R.; Argiles, A.; European Uremic Toxin Work Group. Normal and pathologic concentrations of uremic toxins. J. Am. Soc. Nephrol. JASN 2012, 23, 1258-1270. [CrossRef] [PubMed]

10. Uremic Toxin-Data Base. Available online: http://www.uremic-toxins.org/DataBase.html (accessed on 20 October 2016).

11. Bosch-Panadero, E.; Mas, S.; Sanchez-Ospina, D.; Camarero, V.; Pérez-Gómez, M.V.; Saez-Calero, I.; Abaigar, P.; Ortiz, A.; Egido, J.; González-Parra, E. The Choice of Hemodialysis Membrane Affects Bisphenol A Levels in Blood. J. Am. Soc. Nephrol. JASN 2016, 27, 1566-1574. [CrossRef] [PubMed]

12. González-Parra, E.; Herrero, J.A.; Elewa, U.; Bosch, R.J.; Arduán, A.O.; Egido, J. Bisphenol a in chronic kidney disease. Int. J. Nephrol. 2013, 2013, 437857. [CrossRef] [PubMed]

13. Lederberg, J.; McCray, A.T. 'Ome Sweet' Omics-A Genealogical Treasury of Words Genealogical Treasury of Words. Scientist 2001, 15, 8.

14. Sabatino, A.; Regolisti, G.; Brusasco, I.; Cabassi, A.; Morabito, S.; Fiaccadori, E. Alterations of intestinal barrier and microbiota in chronic kidney disease. Nephrol. Dial. Transplant. 2015, 30, 924-933. [CrossRef] [PubMed]

15. Anand, P.K.; Malireddi, R.K.S.; Lukens, J.R.; Vogel, P.; Bertin, J.; Lamkanfi, M.; Kanneganti, T.-D. NLRP6 negatively regulates innate immunity and host defence against bacterial pathogens. Nature 2012, 488, 389-393. [CrossRef] [PubMed]

16. Borges, N.A.; Barros, A.F.; Nakao, L.S.; Dolenga, C.J.; Fouque, D.; Mafra, D. Protein-Bound Uremic Toxins from Gut Microbiota and Inflammatory Markers in Chronic Kidney Disease. J. Ren. Nutr. 2016, 26, 396-400. [CrossRef] [PubMed]

17. Khan, M.T.; Nieuwdorp, M.; Bäckhed, F. Microbial modulation of insulin sensitivity. Cell Metab. 2014, 20, 753-760. [CrossRef] [PubMed] 
18. Integrative HMP (iHMP) Research Network Consortium. The Integrative Human Microbiome Project: Dynamic analysis of microbiome-host omics profiles during periods of human health and disease. Cell Host Microbe 2014, 16, 276-289.

19. iHMP. Available online: http:/ / hmp2.org (accessed on 20 April 2017).

20. Johnson, A.M.F.; Olefsky, J.M. The origins and drivers of insulin resistance. Cell 2013, 152, 673-684. [CrossRef] [PubMed]

21. Cigarran Guldris, S.; González Parra, E.; Cases Amenós, A. Gut microbiota in chronic kidney disease. Nefrologia 2017, 37, 9-19. [CrossRef] [PubMed]

22. Vaziri, N.D.; Wong, J.; Pahl, M.; Piceno, Y.M.; Yuan, J.; DeSantis, T.Z.; Ni, Z.; Nguyen, T.-H.; Andersen, G.L. Chronic kidney disease alters intestinal microbial flora. Kidney Int. 2013, 83, 308-315. [CrossRef] [PubMed]

23. Wong, J.; Piceno, Y.M.; Desantis, T.Z.; Pahl, M.; Andersen, G.L.; Vaziri, N.D. Expansion of urease- and uricase-containing, indole- and p-cresol-forming and contraction of short-chain fatty acid-producing intestinal microbiota in ESRD. Am. J. Nephrol. 2014, 39, 230-237. [CrossRef] [PubMed]

24. Gonzalez-Parra, E.; Tuñón, J.; Egido, J.; Ortiz, A. Phosphate: A stealthier killer than previously thought? Cardiovasc. Pathol. 2012, 21, 372-381. [CrossRef] [PubMed]

25. Isakova, T.; Gutiérrez, O.M.; Wolf, M. A blueprint for randomized trials targeting phosphorus metabolism in chronic kidney disease. Kidney Int. 2009, 76, 705-716. [CrossRef] [PubMed]

26. Tonelli, M.; Sacks, F.; Pfeffer, M.; Gao, Z.; Curhan, G.; Cholesterol and Recurrent Events Trial Investigators. Relation between serum phosphate level and cardiovascular event rate in people with coronary disease. Circulation 2005, 112, 2627-2633. [CrossRef] [PubMed]

27. Dhingra, R.; Sullivan, L.M.; Fox, C.S.; Wang, T.J.; D'Agostino, R.B.; Gaziano, J.M.; Vasan, R.S. Relations of serum phosphorus and calcium levels to the incidence of cardiovascular disease in the community. Arch. Intern. Med. 2007, 167, 879-885. [CrossRef] [PubMed]

28. Van Kuijk, J.-P.; Flu, W.-J.; Chonchol, M.; Valentijn, T.M.; Verhagen, H.J.M.; Bax, J.J.; Poldermans, D. Elevated preoperative phosphorus levels are an independent risk factor for cardiovascular mortality. Am. J. Nephrol. 2010, 32, 163-168. [CrossRef] [PubMed]

29. Foley, R.N.; Collins, A.J.; Ishani, A.; Kalra, P.A. Calcium-phosphate levels and cardiovascular disease in community-dwelling adults: The Atherosclerosis Risk in Communities (ARIC) Study. Am. Heart J. 2008, 156, 556-563. [CrossRef] [PubMed]

30. Zoccali, C.; Ruggenenti, P.; Perna, A.; Leonardis, D.; Tripepi, R.; Tripepi, G.; Mallamaci, F.; Remuzzi, G.; REIN Study Group. Phosphate may promote CKD progression and attenuate renoprotective effect of ACE inhibition. J. Am. Soc. Nephrol. JASN 2011, 22, 1923-1930. [CrossRef] [PubMed]

31. Isakova, T.; Gutiérrez, O.M.; Chang, Y.; Shah, A.; Tamez, H.; Smith, K.; Thadhani, R.; Wolf, M. Phosphorus binders and survival on hemodialysis. J. Am. Soc. Nephrol. JASN 2009, 20, 388-396. [CrossRef] [PubMed]

32. Hénaut, L.; Sanz, A.B.; Martin-Sanchez, D.; Carrasco, S.; Villa-Bellosta, R.; Aldamiz-Echevarria, G.; Massy, Z.A.; Sanchez-Nino, M.D.; Ortiz, A. TWEAK favors phosphate-induced calcification of vascular smooth muscle cells through canonical and non-canonical activation of NFkB. Cell Death Dis. 2016, 7, e2305. [CrossRef] [PubMed]

33. Shuto, E.; Taketani, Y.; Tanaka, R.; Harada, N.; Isshiki, M.; Sato, M.; Nashiki, K.; Amo, K.; Yamamoto, H.; Higashi, Y.; et al. Dietary phosphorus acutely impairs endothelial function. J. Am. Soc. Nephrol. JASN 2009, 20, 1504-1512. [CrossRef] [PubMed]

34. Saito, H.; Kusano, K.; Kinosaki, M.; Ito, H.; Hirata, M.; Segawa, H.; Miyamoto, K.-I.; Fukushima, N. Human fibroblast growth factor-23 mutants suppress $\mathrm{Na}+$-dependent phosphate co-transport activity and 1alpha,25-dihydroxyvitamin D3 production. J. Biol. Chem. 2003, 278, 2206-2211. [CrossRef] [PubMed]

35. Urakawa, I.; Yamazaki, Y.; Shimada, T.; Iijima, K.; Hasegawa, H.; Okawa, K.; Fujita, T.; Fukumoto, S.; Yamashita, T. Klotho converts canonical FGF receptor into a specific receptor for FGF23. Nature 2006, 444, 770-774. [CrossRef] [PubMed]

36. Moreno, J.A.; Izquierdo, M.C.; Sanchez-Niño, M.D.; Suárez-Alvarez, B.; Lopez-Larrea, C.; Jakubowski, A.; Blanco, J.; Ramirez, R.; Selgas, R.; Ruiz-Ortega, M.; et al. The inflammatory cytokines TWEAK and TNF $\alpha$ reduce renal klotho expression through NFkB. J. Am. Soc. Nephrol. JASN 2011, 22, 1315-1325. [CrossRef] [PubMed] 
37. De Seigneux, S.; Courbebaisse, M.; Rutkowski, J.M.; Wilhelm-Bals, A.; Metzger, M.; Khodo, S.N.; Hasler, U.; Chehade, H.; Dizin, E.; Daryadel, A.; et al. Proteinuria Increases Plasma Phosphate by Altering Its Tubular Handling. J. Am. Soc. Nephrol. JASN 2015, 26, 1608-1618. [CrossRef] [PubMed]

38. Morishita, K.; Shirai, A.; Kubota, M.; Katakura, Y.; Nabeshima, Y.; Takeshige, K.; Kamiya, T. The progression of aging in klotho mutant mice can be modified by dietary phosphorus and zinc. J. Nutr. 2001, 131, 3182-3188. [PubMed]

39. Gutierrez, O.; Isakova, T.; Rhee, E.; Shah, A.; Holmes, J.; Collerone, G.; Jüppner, H.; Wolf, M. Fibroblast growth factor-23 mitigates hyperphosphatemia but accentuates calcitriol deficiency in chronic kidney disease. J. Am. Soc. Nephrol. JASN 2005, 16, 2205-2215. [CrossRef] [PubMed]

40. Rossaint, J.; Oehmichen, J.; Van Aken, H.; Reuter, S.; Pavenstädt, H.J.; Meersch, M.; Unruh, M.; Zarbock, A. FGF23 signaling impairs neutrophil recruitment and host defense during CKD. J. Clin. Investig. 2016, 126, 962-974. [CrossRef] [PubMed]

41. González-Parra, E.; Aceña, Á.; Lorenzo, Ó.; Tarín, N.; González-Casaus, M.L.; Cristóbal, C.; Huelmos, A.; Mahíllo-Fernández, I.; Pello, A.M.; Carda, R.; et al. Important abnormalities of bone mineral metabolism are present in patients with coronary artery disease with a mild decrease of the estimated glomerular filtration rate. J. Bone Miner. Metab. 2016, 34, 587-598. [CrossRef] [PubMed]

42. Tuñón, J.; Fernández-Fernández, B.; Carda, R.; Pello, A.M.; Cristóbal, C.; Tarín, N.; Aceña, Á.; González-Casaus, M.L.; Huelmos, A.; Alonso, J.; et al. Circulating fibroblast growth factor-23 plasma levels predict adverse cardiovascular outcomes in patients with diabetes mellitus with coronary artery disease. Diabetes Metab. Res. Rev. 2016, 32, 685-693. [CrossRef] [PubMed]

43. Aceña, Á.; Pello, A.M.; Carda, R.; Lorenzo, Ó.; Gonzalez-Casaus, M.L.; Blanco-Colio, L.M.; Martín-Ventura, J.L.; Palfy, J.; Orejas, M.; Rábago, R.; et al. Parathormone Levels Are Independently Associated with the Presence of Left Ventricular Hypertrophy in Patients with Coronary Artery Disease. J. Nutr. Health Aging 2016, 20, 659-664. [CrossRef] [PubMed]

44. Tuñón, J.; Cristóbal, C.; Tarín, N.; Aceña, Á.; González-Casaus, M.L.; Huelmos, A.; Alonso, J.; Lorenzo, Ó.; González-Parra, E.; Mahíllo-Fernández, I.; et al. Coexistence of low vitamin D and high fibroblast growth factor-23 plasma levels predicts an adverse outcome in patients with coronary artery disease. PLoS ONE 2014, 9, e95402. [CrossRef] [PubMed]

45. Leelarungrayub, J.; Yankai, A.; Pinkaew, D.; Puntumetakul, R.; Laskin, J.J.; Bloomer, R.J. A preliminary study on the effects of star fruit consumption on antioxidant and lipid status in elderly Thai individuals. Clin. Interv. Aging 2016, 11, 1183-1192. [CrossRef] [PubMed]

46. Leelarungrayub, J.; Laskin, J.J.; Bloomer, R.J.; Pinkaew, D. Consumption of star fruit juice on pro-inflammatory markers and walking distance in the community dwelling elderly. Arch. Gerontol. Geriatr. 2016, 64, 6-12. [CrossRef] [PubMed]

47. Xie, Q.; Zhang, S.; Chen, C.; Li, J.; Wei, X.; Xu, X.; Xuan, F.; Chen, N.; Pham, T.; Qin, N.; et al. Protective Effect of 2-Dodecyl-6-Methoxycyclohexa-2, 5-Diene-1, 4-Dione, Isolated from Averrhoa carambola, L., Against Palmitic Acid-Induced Inflammation and Apoptosis in Min6 Cells by Inhibiting the TLR4-MyD88-NF- $\mathrm{B}$ Signaling Pathway. Cell. Physiol. Biochem. 2016, 39, 1705-1715. [CrossRef] [PubMed]

48. Muir, C.K.; Lam, C.K. Depressant action of Averrhoa carambola. Med. J. Malays. 1980, 34, 279-280.

49. Garcia-Cairasco, N.; Moyses-Neto, M.; Del Vecchio, F.; Oliveira, J.A.C.; dos Santos, F.L.; Castro, O.W.; Arisi, G.M.; Dantas, M.; Carolino, R.O.G.; Coutinho-Netto, J.; et al. Elucidating the neurotoxicity of the star fruit. Angew. Chem. Int. Ed. 2013, 52, 13067-13070. [CrossRef] [PubMed]

50. De Oliveira, E.S.M.; de Aguiar, A.S. Why eating star fruit is prohibited for patients with chronic kidney disease? J. Bras. Nefrol. 2015, 37, 241-247. [CrossRef] [PubMed]

51. Abeysekera, R.A.; Wijetunge, S.; Nanayakkara, N.; Wazil, A.W.M.; Ratnatunga, N.V.I.; Jayalath, T.; Medagama, A. Star fruit toxicity: A cause of both acute kidney injury and chronic kidney disease: A report of two cases. BMC Res. Notes 2015, 8, 796. [CrossRef] [PubMed]

52. Neto, M.M.; Silva, G.E.B.; Costa, R.S.; Vieira Neto, O.M.; Garcia-Cairasco, N.; Lopes, N.P.; Haendchen, P.F.C.; Silveira, C.; Mendes, A.R.; Filho, R.R.; et al. Star fruit: Simultaneous neurotoxic and nephrotoxic effects in people with previously normal renal function. NDT Plus 2009, 2, 485-488. [CrossRef] [PubMed]

53. Neto, M.M.; da Costa, J.A.C.; Garcia-Cairasco, N.; Netto, J.C.; Nakagawa, B.; Dantas, M. Intoxication by star fruit (Averrhoa carambola) in 32 uraemic patients: Treatment and outcome. Nephrol. Dial. Transplant. 2003, 18, 120-125. [CrossRef] [PubMed] 
54. Fang, H.-C.; Lee, P.-T.; Lu, P.-J.; Chen, C.-L.; Chang, T.-Y.; Hsu, C.-Y.; Chung, H.-M.; Chou, K.-J. Mechanisms of star fruit-induced acute renal failure. Food Chem. Toxicol. 2008, 46, 1744-1752. [CrossRef] [PubMed]

55. Husi, H.; Sanchez-Niño, M.D.; Delles, C.; Mullen, W.; Vlahou, A.; Ortiz, A.; Mischak, H. A combinatorial approach of Proteomics and Systems Biology in unravelling the mechanisms of acute kidney injury (AKI): Involvement of NMDA receptor GRIN1 in murine AKI. BMC Syst. Biol. 2013, 7, 110. [CrossRef] [PubMed]

56. Mydlík, M.; Derzsiová, K. Oxalic Acid as a uremic toxin. J. Ren. Nutr. 2008, 18, 33-39. [CrossRef] [PubMed]

57. Poesen, R.; Meijers, B.; Evenepoel, P. The colon: An overlooked site for therapeutics in dialysis patients. Semin. Dial. 2013, 26, 323-332. [CrossRef] [PubMed]

58. Getting, J.E.; Gregoire, J.R.; Phul, A.; Kasten, M.J. Oxalate nephropathy due to "juicing": Case report and review. Am. J. Med. 2013, 126, 768-772. [CrossRef] [PubMed]

59. Zeisel, S.H.; da Costa, K.-A. Choline: An essential nutrient for public health. Nutr. Rev. 2009, 67, 615-623. [CrossRef] [PubMed]

60. Hollenbeck, C.B. An introduction to the nutrition and metabolism of choline. Cent. Nerv. Syst. Agents Med. Chem. 2012, 12, 100-113. [CrossRef] [PubMed]

61. Institute of Medicine (US) Standing Committee on the Scientific Evaluation of Dietary Reference Intakes and its Panel on Folate, Other B Vitamins, and Choline. In Dietary Reference Intakes for Thiamin, Riboflavin, Niacin, Vitamin B6, Folate, Vitamin B12, Pantothenic Acid, Biotin, and Choline; National Academies Press: Washington, DC, USA, 1998.

62. USDA Nutrients Database. Available online: https://ndb.nal.usda.gov/ndb/ (accessed on 22 April 2017).

63. Rennick, B.; Acara, M.; Hysert, P.; Mookerjee, B. Choline loss during hemodialysis: Homeostatic control of plasma choline concentrations. Kidney Int. 1976, 10, 329-335. [CrossRef] [PubMed]

64. Jiang, X.; West, A.A.; Caudill, M.A. Maternal choline supplementation: A nutritional approach for improving offspring health? Trends Endocrinol. Metab. TEM 2014, 25, 263-273. [CrossRef] [PubMed]

65. Mi, W.; van Wijk, N.; Cansev, M.; Sijben, J.W.C.; Kamphuis, P.J.G.H. Nutritional approaches in the risk reduction and management of Alzheimer's disease. Nutrition 2013, 29, 1080-1089. [CrossRef] [PubMed]

66. Conlay, L.A.; Wurtman, R.J.; Blusztajn, K.; Coviella, I.L.; Maher, T.J.; Evoniuk, G.E. Decreased plasma choline concentrations in marathon runners. N. Engl. J. Med. 1986, 315, 892. [PubMed]

67. Buchman, A.L.; Awal, M.; Jenden, D.; Roch, M.; Kang, S.H. The effect of lecithin supplementation on plasma choline concentrations during a marathon. J. Am. Coll. Nutr. 2000, 19, 768-770. [CrossRef] [PubMed]

68. Leermakers, E.T.M.; Moreira, E.M.; Kiefte-de Jong, J.C.; Darweesh, S.K.L.; Visser, T.; Voortman, T.; Bautista, P.K.; Chowdhury, R.; Gorman, D.; Bramer, W.M.; et al. Effects of choline on health across the life course: A systematic review. Nutr. Rev. 2015, 73, 500-522. [CrossRef] [PubMed]

69. Boyd, W.D.; Graham-White, J.; Blackwood, G.; Glen, I.; McQueen, J. Clinical effects of choline in Alzheimer senile dementia. Lancet 1977, 2, 711. [CrossRef]

70. Sanchez-Niño, M.D.; Ortiz, A. Differential effects of oral and intravenous l-carnitine on serum lipids: Is the microbiota the answer? Clin. Kidney J. 2014, 7, 437-441. [CrossRef] [PubMed]

71. Steiber, A.; Kerner, J.; Hoppel, C.L. Carnitine: A nutritional, biosynthetic, and functional perspective. Mol. Asp. Med. 2004, 25, 455-473. [CrossRef] [PubMed]

72. Guarnieri, G. Carnitine in maintenance hemodialysis patients. J. Ren. Nutr. 2015, 25, 169-175. [CrossRef] [PubMed]

73. Rospond, B.; Chłopicka, J. The biological function of L-carnitine and its content in the particular food examples. Prz. Lek. 2013, 70, 85-91. [PubMed]

74. Evans, A. Dialysis-related carnitine disorder and levocarnitine pharmacology. Am. J. Kidney Dis. 2003, 41, S13-S26. [CrossRef]

75. Evans, A.M.; Fornasini, G. Pharmacokinetics of L-Carnitine. Clin. Pharmacokinet. 2003, 42, 941-967. [CrossRef] [PubMed]

76. Bain, M.A.; Milne, R.W.; Evans, A.M. Disposition and metabolite kinetics of oral L-carnitine in humans. J. Clin. Pharmacol. 2006, 46, 1163-1170. [CrossRef] [PubMed]

77. Kerner, J.; Hoppel, C. Genetic disorders of carnitine metabolism and their nutritional management. Ann. Rev. Nutr. 1998, 18, 179-206. [CrossRef] [PubMed]

78. Kalim, S.; Clish, C.B.; Wenger, J.; Elmariah, S.; Yeh, R.W.; Deferio, J.J.; Pierce, K.; Deik, A.; Gerszten, R.E.; Thadhani, R.; et al. A plasma long-chain acylcarnitine predicts cardiovascular mortality in incident dialysis patients. J. Am. Heart Assoc. 2013, 2, e000542. [CrossRef] [PubMed] 
79. Centers for Medicare \& Medicaid Services (CMS); United States Department of Health and Human Services (HHS). Medicare program; end-stage renal disease quality incentive program. Final rule. Fed. Regist. 2011, 76, 627-646.

80. Wasserstein, A.G. L-carnitine supplementation in dialysis: Treatment in quest of disease. Semin. Dial. 2013, 26, 11-15. [CrossRef] [PubMed]

81. Clinical practice guidelines for nutrition in chronic renal failure. K/DOQI, National Kidney Foundation. Am. J. Kidney Dis. 2000, 35, S1-S140.

82. KDOQI Work Group. KDOQI Clinical Practice Guideline for Nutrition in Children with CKD: 2008 update. Executive summary. Am. J. Kidney Dis. 2009, 53, S11-S104.

83. Kidney Disease: Improving Global Outcomes (KDIGO) Anemia Work Group. KDIGO Clinical Practice Guideline for Anemia in Chronic Kidney Disease. Kidney Int. Suppl. 2012, 2, 279.

84. Kliger, A.S.; Foley, R.N.; Goldfarb, D.S.; Goldstein, S.L.; Johansen, K.; Singh, A.; Szczech, L. KDOQI US commentary on the 2012 KDIGO Clinical Practice Guideline for Anemia in CKD. Am. J. Kidney Dis. 2013, 62, 849-859. [CrossRef] [PubMed]

85. Molyneux, R.; Seymour, A.-M.; Bhandari, S. Value of carnitine therapy in kidney dialysis patients and effects on cardiac function from human and animal studies. Curr. Drug Targets 2012, 13, 285-293. [CrossRef] [PubMed]

86. Chen, Y.; Abbate, M.; Tang, L.; Cai, G.; Gong, Z.; Wei, R.; Zhou, J.; Chen, X. L-Carnitine supplementation for adults with end-stage kidney disease requiring maintenance hemodialysis: A systematic review and meta-analysis. Am. J. Clin. Nutr. 2014, 99, 408-422. [CrossRef] [PubMed]

87. Moraes, C.; Fouque, D.; Amaral, A.C.F.; Mafra, D. Trimethylamine N-Oxide From Gut Microbiota in Chronic Kidney Disease Patients: Focus on Diet. J. Ren. Nutr. 2015, 25, 459-465. [CrossRef] [PubMed]

88. Koeth, R.A.; Wang, Z.; Levison, B.S.; Buffa, J.A.; Org, E.; Sheehy, B.T.; Britt, E.B.; Fu, X.; Wu, Y.; Li, L.; et al. Intestinal microbiota metabolism of L-carnitine, a nutrient in red meat, promotes atherosclerosis. Nat. Med. 2013, 19, 576-585. [CrossRef] [PubMed]

89. Zhang, A.Q.; Mitchell, S.C.; Smith, R.L. Dietary precursors of trimethylamine in man: A pilot study. Food Chem. Toxicol. 1999, 37, 515-520. [CrossRef]

90. Ufnal, M.; Zadlo, A.; Ostaszewski, R. TMAO: A small molecule of great expectations. Nutrition 2015, 31, 1317-1323. [CrossRef] [PubMed]

91. Ferreira, F.; Esteves, S.; Almeida, L.S.; Gaspar, A.; da Costa, C.D.; Janeiro, P.; Bandeira, A.; Martins, E.; Teles, E.L.; Garcia, P.; et al. Trimethylaminuria (fish odor syndrome): Genotype characterization among Portuguese patients. Gene 2013, 527, 366-370. [CrossRef] [PubMed]

92. Bain, M.A.; Faull, R.; Fornasini, G.; Milne, R.W.; Evans, A.M. Accumulation of trimethylamine and trimethylamine-N-oxide in end-stage renal disease patients undergoing haemodialysis. Nephrol. Dial. Transplant. 2006, 21, 1300-1304. [CrossRef] [PubMed]

93. Tang, W.H.W.; Wang, Z.; Kennedy, D.J.; Wu, Y.; Buffa, J.A.; Agatisa-Boyle, B.; Li, X.S.; Levison, B.S.; Hazen, S.L. Gut microbiota-dependent trimethylamine N-oxide (TMAO) pathway contributes to both development of renal insufficiency and mortality risk in chronic kidney disease. Circ. Res. 2015, 116, 448-455. [CrossRef] [PubMed]

94. Posada-Ayala, M.; Zubiri, I.; Martin-Lorenzo, M.; Sanz-Maroto, A.; Molero, D.; Gonzalez-Calero, L.; Fernandez-Fernandez, B.; de la Cuesta, F.; Laborde, C.M.; Barderas, M.G.; et al. Identification of a urine metabolomic signature in patients with advanced-stage chronic kidney disease. Kidney Int. 2014, 85, 103-111. [CrossRef] [PubMed]

95. Miller, C.A.; Corbin, K.D.; da Costa, K.-A.; Zhang, S.; Zhao, X.; Galanko, J.A.; Blevins, T.; Bennett, B.J.; O'Connor, A.; Zeisel, S.H. Effect of egg ingestion on trimethylamine- $N$-oxide production in humans: A randomized, controlled, dose-response study. Am. J. Clin. Nutr. 2014, 100, 778-786. [CrossRef] [PubMed]

96. McEntyre, C.J.; Lever, M.; Chambers, S.T.; George, P.M.; Slow, S.; Elmslie, J.L.; Florkowski, C.M.; Lunt, H.; Krebs, J.D. Variation of betaine, $N, N$-dimethylglycine, choline, glycerophosphorylcholine, taurine and trimethylamine-N-oxide in the plasma and urine of overweight people with type 2 diabetes over a two-year period. Ann. Clin. Biochem. 2015, 52, 352-360. [CrossRef] [PubMed]

97. Bain, M.A.; Faull, R.; Milne, R.W.; Evans, A.M. Oral L-carnitine: Metabolite formation and hemodialysis. Curr. Drug Metab. 2006, 7, 811-816. [CrossRef] [PubMed] 
98. Ozasa, H.; Shimizu, M.; Koizumi, A.; Wakabayashi, A.; Yamazaki, H. Trimethylamine generation in patients receiving hemodialysis treated with 1-carnitine. Clin. Kidney J. 2014, 7, 329. [CrossRef] [PubMed]

99. Kuhlmann, M.K.; Yoshino, M.; Levin, N.W. Differences in cardiovascular mortality rates among hemodialysis patients in the United States and Japan: The importance of background cardiovascular mortality. Hemodialysis international. Int. Symp. Home Hemodial. 2004, 8, 394-399. [CrossRef] [PubMed]

100. Shafi, T.; Powe, N.R.; Meyer, T.W.; Hwang, S.; Hai, X.; Melamed, M.L.; Banerjee, T.; Coresh, J.; Hostetter, T.H. Trimethylamine N-Oxide and Cardiovascular Events in Hemodialysis Patients. J. Am. Soc. Nephrol. JASN 2017, 28, 321-331. [CrossRef] [PubMed]

101. Tang, W.H.W.; Wang, Z.; Levison, B.S.; Koeth, R.A.; Britt, E.B.; Fu, X.; Wu, Y.; Hazen, S.L. Intestinal microbial metabolism of phosphatidylcholine and cardiovascular risk. N. Engl. J. Med. 2013, 368, 1575-1584. [CrossRef] [PubMed]

102. Lew, Q.-L.J.; Jafar, T.H.; Koh, H.W.L.; Jin, A.; Chow, K.Y.; Yuan, J.-M.; Koh, W.-P. Red Meat Intake and Risk of ESRD. J. Am. Soc. Nephrol. JASN 2017, 28, 304-312. [CrossRef] [PubMed]

103. Wang, Z.; Klipfell, E.; Bennett, B.J.; Koeth, R.; Levison, B.S.; Dugar, B.; Feldstein, A.E.; Britt, E.B.; Fu, X.; Chung, Y.-M.; et al. Gut flora metabolism of phosphatidylcholine promotes cardiovascular disease. Nature 2011, 472, 57-63. [CrossRef] [PubMed]

104. Tang, W.H.W.; Hazen, S.L. Microbiome, trimethylamine N-oxide, and cardiometabolic disease. Transl. Res. 2017, 179, 108-115. [CrossRef] [PubMed]

105. Aron-Wisnewsky, J.; Clément, K. The gut microbiome, diet, and links to cardiometabolic and chronic disorders. Nat. Rev. Nephrol. 2016, 12, 169-181. [CrossRef] [PubMed]

106. Senthong, V.; Li, X.S.; Hudec, T.; Coughlin, J.; Wu, Y.; Levison, B.; Wang, Z.; Hazen, S.L.; Tang, W.H.W. Plasma Trimethylamine N-Oxide, a Gut Microbe-Generated Phosphatidylcholine Metabolite, Is Associated With Atherosclerotic Burden. J. Am. Coll. Cardiol. 2016, 67, 2620-2628. [CrossRef] [PubMed]

107. Obeid, R.; Awwad, H.M.; Rabagny, Y.; Graeber, S.; Herrmann, W.; Geisel, J. Plasma trimethylamine N-oxide concentration is associated with choline, phospholipids, and methyl metabolism. Am. J. Clin. Nutr. 2016, 103, 703-711. [CrossRef] [PubMed]

108. Tang, W.H.W.; Wang, Z.; Fan, Y.; Levison, B.; Hazen, J.E.; Donahue, L.M.; Wu, Y.; Hazen, S.L. Prognostic value of elevated levels of intestinal microbe-generated metabolite trimethylamine- $N$-oxide in patients with heart failure: Refining the gut hypothesis. J. Am. Coll. Cardiol. 2014, 64, 1908-1914. [CrossRef] [PubMed]

109. Suzuki, T.; Heaney, L.M.; Bhandari, S.S.; Jones, D.J.L.; Ng, L.L. Trimethylamine N-oxide and prognosis in acute heart failure. Heart (Br. Card. Soc.) 2016, 102, 841-848.

110. Ma, J.; Pazos, I.M.; Gai, F. Microscopic insights into the protein-stabilizing effect of trimethylamine N-oxide (TMAO). Proc. Natl. Acad. Sci. USA 2014, 111, 8476-8481. [CrossRef] [PubMed]

111. Zhu, W.; Gregory, J.C.; Org, E.; Buffa, J.A.; Gupta, N.; Wang, Z.; Li, L.; Fu, X.; Wu, Y.; Mehrabian, M.; et al. Gut Microbial Metabolite TMAO Enhances Platelet Hyperreactivity and Thrombosis Risk. Cell 2016, 165, 111-124. [CrossRef] [PubMed]

112. Tamarappoo, B.K.; Verkman, A.S. Defective aquaporin-2 trafficking in nephrogenic diabetes insipidus and correction by chemical chaperones. J. Clin. Investig. 1998, 101, 2257-2267. [CrossRef] [PubMed]

113. Tatzelt, J.; Prusiner, S.B.; Welch, W.J. Chemical chaperones interfere with the formation of scrapie prion protein. EMBO J. 1996, 15, 6363-6373. [PubMed]

114. Hong, J.; Xiong, S. TMAO-Protein Preferential Interaction Profile Determines TMAO's Conditional In Vivo Compatibility. Biophys. J. 2016, 111, 1866-1875. [CrossRef] [PubMed]

115. Energy and protein requirements. Report of a joint FAO/WHO/UNU Expert Consultation. World Health Organ. Tech. Rep. Ser. 1985, 724, 1-206.

116. Kalim, S.; Clish, C.B.; Deferio, J.J.; Ortiz, G.; Moffet, A.S.; Gerszten, R.E.; Thadhani, R.; Rhee, E.P. Cross-sectional examination of metabolites and metabolic phenotypes in uremia. BMC Nephrol. 2015, 16, 98. [CrossRef] [PubMed]

117. Koenig, P.; Nagl, C.; Neurauter, G.; Schennach, H.; Brandacher, G.; Fuchs, D. Enhanced degradation of tryptophan in patients on hemodialysis. Clin. Nephrol. 2010, 74, 465-470. [CrossRef] [PubMed]

118. Schefold, J.C.; Zeden, J.-P.; Fotopoulou, C.; von Haehling, S.; Pschowski, R.; Hasper, D.; Volk, H.-D.; Schuett, C.; Reinke, P. Increased indoleamine 2,3-dioxygenase (IDO) activity and elevated serum levels of tryptophan catabolites in patients with chronic kidney disease: A possible link between chronic inflammation and uraemic symptoms. Nephrol. Dial. Transplant. 2009, 24, 1901-1908. [CrossRef] [PubMed] 
119. Lovelace, M.D.; Varney, B.; Sundaram, G.; Franco, N.F.; Ng, M.L.; Pai, S.; Lim, C.K.; Guillemin, G.J.; Brew, B.J. Current Evidence for a Role of the Kynurenine Pathway of Tryptophan Metabolism in Multiple Sclerosis. Front. Immunol. 2016, 7, 246. [CrossRef] [PubMed]

120. Ravindran, A.V.; da Silva, T.L. Complementary and alternative therapies as add-on to pharmacotherapy for mood and anxiety disorders: A systematic review. J. Affect. Disord. 2013, 150, 707-719. [CrossRef] [PubMed]

121. Sallée, M.; Dou, L.; Cerini, C.; Poitevin, S.; Brunet, P.; Burtey, S. The aryl hydrocarbon receptor-activating effect of uremic toxins from tryptophan metabolism: A new concept to understand cardiovascular complications of chronic kidney disease. Toxins 2014, 6, 934-949. [CrossRef] [PubMed]

122. Glassock, R.J. Uremic toxins: What are they? An integrated overview of pathobiology and classification. J. Ren. Nutr. 2008, 18, 2-6. [CrossRef] [PubMed]

123. Ellis, R.J.; Small, D.M.; Vesey, D.A.; Johnson, D.W.; Francis, R.; Vitetta, L.; Gobe, G.C.; Morais, C. Indoxyl sulphate and kidney disease: Causes, consequences and interventions. Nephrology 2016, 21, 170-177. [CrossRef] [PubMed]

124. Wing, M.R.; Patel, S.S.; Ramezani, A.; Raj, D.S. Gut microbiome in chronic kidney disease. Exp. Physiol. 2016, 101, 471-477. [CrossRef] [PubMed]

125. Zhang, L.S.; Davies, S.S. Microbial metabolism of dietary components to bioactive metabolites: Opportunities for new therapeutic interventions. Genome Med. 2016, 8, 46. [CrossRef] [PubMed]

126. Chyan, Y.J.; Poeggeler, B.; Omar, R.A.; Chain, D.G.; Frangione, B.; Ghiso, J.; Pappolla, M.A. Potent neuroprotective properties against the Alzheimer beta-amyloid by an endogenous melatonin-related indole structure, indole-3-propionic acid. J. Biol. Chem. 1999, 274, 21937-21942. [CrossRef] [PubMed]

127. Vanholder, R.; Schepers, E.; Pletinck, A.; Nagler, E.V.; Glorieux, G. The uremic toxicity of indoxyl sulfate and p-cresyl sulfate: A systematic review. J. Am. Soc. Nephrol. JASN 2014, 25, 1897-1907. [CrossRef] [PubMed]

128. Barreto, F.C.; Barreto, D.V.; Liabeuf, S.; Meert, N.; Glorieux, G.; Temmar, M.; Choukroun, G.; Vanholder, R.; Massy, Z.A.; European Uremic Toxin Work Group (EUTox). Serum indoxyl sulfate is associated with vascular disease and mortality in chronic kidney disease patients. Clin. J. Am. Soc. Nephrol. CJASN 2009, 4, 1551-1558. [CrossRef] [PubMed]

129. Wu, I.-W.; Hsu, K.-H.; Lee, C.-C.; Sun, C.-Y.; Hsu, H.-J.; Tsai, C.-J.; Tzen, C.-Y.; Wang, Y.-C.; Lin, C.-Y.; $\mathrm{Wu}, \mathrm{M} . \mathrm{S}$. p-Cresyl sulphate and indoxyl sulphate predict progression of chronic kidney disease. Nephrol. Dial. Transplant. 2011, 26, 938-947. [CrossRef] [PubMed]

130. Mutsaers, H.A.M.; Stribos, E.G.D.; Glorieux, G.; Vanholder, R.; Olinga, P. Chronic Kidney Disease and Fibrosis: The Role of Uremic Retention Solutes. Front. Med. 2015, 2, 60. [CrossRef] [PubMed]

131. Buckley, P.D.; Motion, R.L.; Blackwell, L.F.; Hill, J.P. pH effects on cytoplasmic aldehyde dehydrogenase from sheep liver. Adv. Exp. Med. Biol. 1991, 284, 31-41. [PubMed]

132. Hung, S.-C.; Kuo, K.-L.; Huang, H.-L.; Lin, C.-C.; Tsai, T.-H.; Wang, C.-H.; Chen, J.-W.; Lin, S.-J.; Huang, P.-H.; Tarng, D.-C. Indoxyl sulfate suppresses endothelial progenitor cell-mediated neovascularization. Kidney Int. 2016, 89, 574-585. [CrossRef] [PubMed]

133. Shivanna, S.; Kolandaivelu, K.; Shashar, M.; Belghasim, M.; Al-Rabadi, L.; Balcells, M.; Zhang, A.; Weinberg, J.; Francis, J.; Pollastri, M.P.; et al. The Aryl Hydrocarbon Receptor is a Critical Regulator of Tissue Factor Stability and an Antithrombotic Target in Uremia. J. Am. Soc. Nephrol. JASN 2016, 27, 189-201. [CrossRef] [PubMed]

134. Chitalia, V.C.; Shivanna, S.; Martorell, J.; Balcells, M.; Bosch, I.; Kolandaivelu, K.; Edelman, E.R. Uremic serum and solutes increase post-vascular interventional thrombotic risk through altered stability of smooth muscle cell tissue factor. Circulation 2013, 127, 365-376. [CrossRef] [PubMed]

135. Gondouin, B.; Cerini, C.; Dou, L.; Sallée, M.; Duval-Sabatier, A.; Pletinck, A.; Calaf, R.; Lacroix, R.; Jourde-Chiche, N.; Poitevin, S.; et al. Indolic uremic solutes increase tissue factor production in endothelial cells by the aryl hydrocarbon receptor pathway. Kidney Int. 2013, 84, 733-744. [CrossRef] [PubMed]

136. Yang, K.; Du, C.; Wang, X.; Li, F.; Xu, Y.; Wang, S.; Chen, S.; Chen, F.; Shen, M.; Chen, M.; et al. Uremic solute indoxyl sulfate-induced platelet hyperactivity contributes to CKD-associated thrombosis in mice. Blood 2017. [CrossRef] [PubMed]

137. Wu, C.-C.; Hsieh, M.-Y.; Hung, S.-C.; Kuo, K.-L.; Tsai, T.-H.; Lai, C.-L.; Chen, J.-W.; Lin, S.-J.; Huang, P.-H.; Tarng, D.-C. Serum Indoxyl Sulfate Associates with Postangioplasty Thrombosis of Dialysis Grafts. J. Am. Soc. Nephrol. JASN 2016, 27, 1254-1264. [CrossRef] [PubMed] 
138. Wallman, J.; Pettigrew, J.D. Conjugate and disjunctive saccades in two avian species with contrasting oculomotor strategies. J. Neurosci. 1985, 5, 1418-1428. [PubMed]

139. Nangaku, M.; Mimura, I.; Yamaguchi, J.; Higashijima, Y.; Wada, T.; Tanaka, T. Role of uremic toxins in erythropoiesis-stimulating agent resistance in chronic kidney disease and dialysis patients. J. Ren. Nutr. 2015, 25, 160-163. [CrossRef] [PubMed]

140. Nii-Kono, T.; Iwasaki, Y.; Uchida, M.; Fujieda, A.; Hosokawa, A.; Motojima, M.; Yamato, H.; Kurokawa, K.; Fukagawa, M. Indoxyl sulfate induces skeletal resistance to parathyroid hormone in cultured osteoblastic cells. Kidney Int. 2007, 71, 738-743. [CrossRef] [PubMed]

141. Soulage, C.O.; Koppe, L.; Fouque, D. Protein-bound uremic toxins ... new targets to prevent insulin resistance and dysmetabolism in patients with chronic kidney disease. J. Ren. Nutr. 2013, 23, 464-466. [CrossRef] [PubMed]

142. Sato, E.; Mori, T.; Mishima, E.; Suzuki, A.; Sugawara, S.; Kurasawa, N.; Saigusa, D.; Miura, D.; Morikawa-Ichinose, T.; Saito, R.; et al. Metabolic alterations by indoxyl sulfate in skeletal muscle induce uremic sarcopenia in chronic kidney disease. Sci. Rep. 2016, 6, 36618. [CrossRef] [PubMed]

143. Dou, L.; Sallée, M.; Cerini, C.; Poitevin, S.; Gondouin, B.; Jourde-Chiche, N.; Fallague, K.; Brunet, P.; Calaf, R.; Dussol, B.; et al. The cardiovascular effect of the uremic solute indole-3 acetic acid. J. Am. Soc. Nephrol. JASN 2015, 26, 876-887. [CrossRef] [PubMed]

144. Thurmond, J.B.; Freeman, G.B.; Soblosky, J.S.; Ieni, J.R.; Brown, J.W. Effects of dietary tyrosine on L-dopa- and amphetamine-induced changes in locomotor activity and neurochemistry in mice. Pharmacol. Biochem. Behav. 1990, 37, 259-266. [CrossRef]

145. Fernstrom, J.D.; Fernstrom, M.H. Tyrosine, phenylalanine, and catecholamine synthesis and function in the brain. J. Nutr. 2007, 137, 1539S-1547S. [PubMed]

146. Duranton, F.; Lundin, U.; Gayrard, N.; Mischak, H.; Aparicio, M.; Mourad, G.; Daurès, J.-P.; Weinberger, K.M.; Argilés, A. Plasma and urinary amino acid metabolomic profiling in patients with different levels of kidney function. Clin. J. Am. Soc. Nephrol. CJASN 2014, 9, 37-45. [CrossRef] [PubMed]

147. Bergström, J.; Alvestrand, A.; Fürst, P. Plasma and muscle free amino acids in maintenance hemodialysis patients without protein malnutrition. Kidney Int. 1990, 38, 108-114. [CrossRef] [PubMed]

148. Webster, D.; Wildgoose, J. Tyrosine supplementation for phenylketonuria. Cochrane Database Syst. Rev. 2013. [CrossRef]

149. Jongkees, B.J.; Hommel, B.; Kühn, S.; Colzato, L.S. Effect of tyrosine supplementation on clinical and healthy populations under stress or cognitive demands-A review. J. Psychiatr. Res. 2015, 70, 50-57. [CrossRef] [PubMed]

150. Van de Rest, O.; van der Zwaluw, N.L.; de Groot, L.C.P.G.M. Literature review on the role of dietary protein and amino acids in cognitive functioning and cognitive decline. Amino Acids 2013, 45, 1035-1045. [CrossRef] [PubMed]

151. Molnár, G.A.; Kun, S.; Sélley, E.; Kertész, M.; Szélig, L.; Csontos, C.; Böddi, K.; Bogár, L.; Miseta, A.; Wittmann, I. Role of Tyrosine Isomers in Acute and Chronic Diseases Leading to Oxidative Stress-A Review. Curr. Med. Chem. 2016, 23, 667-685. [CrossRef] [PubMed]

152. Martinez, A.W.; Recht, N.S.; Hostetter, T.H.; Meyer, T.W. Removal of P-cresol sulfate by hemodialysis. J. Am. Soc. Nephrol. JASN 2005, 16, 3430-3436. [CrossRef] [PubMed]

153. Gryp, T.; Vanholder, R.; Vaneechoutte, M.; Glorieux, G. p-Cresyl Sulfate. Toxins 2017, 9, 52. [CrossRef] [PubMed]

154. Meert, N.; Schepers, E.; Glorieux, G.; Van Landschoot, M.; Goeman, J.L.; Waterloos, M.-A.; Dhondt, A.; Van der Eycken, J.; Vanholder, R. Novel method for simultaneous determination of p-cresylsulphate and p-cresylglucuronide: Clinical data and pathophysiological implications. Nephrol. Dial. Transplant. 2012, 27, 2388-2396. [CrossRef] [PubMed]

155. Poveda, J.; Sanchez-Niño, M.D.; Glorieux, G.; Sanz, A.B.; Egido, J.; Vanholder, R.; Ortiz, A. P-Cresyl sulphate has pro-inflammatory and cytotoxic actions on human proximal tubular epithelial cells. Nephrol. Dial. Transplant. 2014, 29, 56-64. [CrossRef] [PubMed]

156. Pletinck, A.; Glorieux, G.; Schepers, E.; Cohen, G.; Gondouin, B.; Van Landschoot, M.; Eloot, S.; Rops, A.; Van de Voorde, J.; De Vriese, A.; et al. Protein-bound uremic toxins stimulate crosstalk between leukocytes and vessel wall. J. Am. Soc. Nephrol. JASN 2013, 24, 1981-1994. [CrossRef] [PubMed] 
157. Liabeuf, S.; Barreto, D.V.; Barreto, F.C.; Meert, N.; Glorieux, G.; Schepers, E.; Temmar, M.; Choukroun, G.; Vanholder, R.; Massy, Z.A.; et al. Free p-cresylsulphate is a predictor of mortality in patients at different stages of chronic kidney disease. Nephrol. Dial. Transplant. 2010, 25, 1183-1191. [CrossRef] [PubMed]

158. Yamaguchi, J.; Tanaka, T.; Inagi, R. Effect of AST-120 in Chronic Kidney Disease Treatment: Still a Controversy? Nephron 2017, 135, 201-206. [CrossRef] [PubMed]

159. Schulman, G.; Berl, T.; Beck, G.J.; Remuzzi, G.; Ritz, E.; Arita, K.; Kato, A.; Shimizu, M. Randomized Placebo-Controlled EPPIC Trials of AST-120 in CKD. J. Am. Soc. Nephrol. JASN 2015, 26, 1732-1746. [CrossRef] [PubMed]

160. Emal, D.; Rampanelli, E.; Stroo, I.; Butter, L.M.; Teske, G.J.; Claessen, N.; Stokman, G.; Florquin, S.; Leemans, J.C.; Dessing, M.C. Depletion of Gut Microbiota Protects against Renal Ischemia-Reperfusion Injury. J. Am. Soc. Nephrol. JASN 2016. [CrossRef] [PubMed]

161. Mishima, E.; Fukuda, S.; Shima, H.; Hirayama, A.; Akiyama, Y.; Takeuchi, Y.; Fukuda, N.N.; Suzuki, T.; Suzuki, C.; Yuri, A.; et al. Alteration of the Intestinal Environment by Lubiprostone Is Associated with Amelioration of Adenine-Induced CKD. J. Am. Soc. Nephrol. JASN 2015, 26, 1787-1794. [CrossRef] [PubMed]

162. Mafra, D.; Fouque, D. Gut microbiota and inflammation in chronic kidney disease patients. Clin. Kidney J. 2015, 8, 332-334. [CrossRef] [PubMed]

163. Koppe, L.; Mafra, D.; Fouque, D. Probiotics and chronic kidney disease. Kidney Int. 2015, 88, 958-966. [CrossRef] [PubMed]

164. Ramezani, A.; Massy, Z.A.; Meijers, B.; Evenepoel, P.; Vanholder, R.; Raj, D.S. Role of the Gut Microbiome in Uremia: A Potential Therapeutic Target. Am. J. Kidney Dis. 2016, 67, 483-498. [CrossRef] [PubMed]

165. Meijers, B.K.I.; De Preter, V.; Verbeke, K.; Vanrenterghem, Y.; Evenepoel, P. p-Cresyl sulfate serum concentrations in haemodialysis patients are reduced by the prebiotic oligofructose-enriched inulin. Nephrol. Dial. Transplant. 2010, 25, 219-224. [CrossRef] [PubMed]

166. Rossi, M.; Johnson, D.W.; Morrison, M.; Pascoe, E.M.; Coombes, J.S.; Forbes, J.M.; Szeto, C.-C.; McWhinney, B.C.; Ungerer, J.P.J.; Campbell, K.L. Synbiotics Easing Renal Failure by Improving Gut Microbiology (SYNERGY): A Randomized Trial. Clin. J. Am. Soc. Nephrol. CJASN 2016, 11, $223-231$. [CrossRef] [PubMed]

167. Nakabayashi, I.; Nakamura, M.; Kawakami, K.; Ohta, T.; Kato, I.; Uchida, K.; Yoshida, M. Effects of synbiotic treatment on serum level of $\mathrm{p}$-cresol in haemodialysis patients: A preliminary study. Nephrol. Dial. Transplant. 2011, 26, 1094-1098. [CrossRef] [PubMed]

168. Tang, W.H.W.; Hazen, S.L. The contributory role of gut microbiota in cardiovascular disease. J. Clin. Investig. 2014, 124, 4204-4211. [CrossRef] [PubMed]

(C) 2017 by the authors. Licensee MDPI, Basel, Switzerland. This article is an open access article distributed under the terms and conditions of the Creative Commons Attribution (CC BY) license (http://creativecommons.org/licenses/by/4.0/). 